\title{
Religion as a Social Capital in Realizing Disaster Resilience in Aceh
}

\author{
Fajri M Kasim ${ }^{1, *}$ Abidin Nurdin ${ }^{2}$ \\ ${ }^{1}$ Faculty of Social and Political Sciences, Universitas Malikussaleh, Aceh Utara, Indonesia \\ ${ }^{2}$ Faculty of Social and Political Sciences, Universitas Malikussaleh, Aceh Utara, Indonesia \\ *Corresponding author.Email: fajrimkasim@gmail.com,fajri@unimal.ac.id
}

\begin{abstract}
This study examines religion as a social capital in realizing disaster resilience in Banda Aceh. The aim of the longterm research is to trace and find the normative dimensions and religious values that are capable of being the spirit of the Acehnese people to survive the disaster and tsunami which are also full of religious values. Another objective of this study is what norms serve as social capital so that people can survive disasters. This is the specific target of research wanting to explore why the people of Aceh are able to survive the disaster, what social capital is owned by the people of Aceh. The type of research used is qualitative, namely research procedures that produce descriptive data in the form of written or spoken words from people and behavior. that can be observed. While the approach used is ethnography which is commonly used in social research. Ethnography is a written description of social organization, social activities, symbols and materials and characteristics of a group's interpretation practices. With an ethnographic approach, namely a written description of the way of life of the community. The data collection techniques used were observation, interview and document study. The results showed that religion is capable of being a social capital, as well as having norms and values such as; tauhid, patience, tawakkal and ikhlas which can be used as social capital in realizing resilience in Aceh.
\end{abstract}

Keywords: religion, social capital, norms and values, disaster resilience

\section{INTRODUCTION}

\subsection{Background}

Geologically, Indonesia is above the cross of three large tectonic plates, namely the Indo-Australia, Eurasia, and the Pacific plates. The meeting zone between the Indo-Australian Plate and the Eurasian plate off the west coast of Sumatra, southern Java, and Nusa Tenggara, while with the Pacific plate in the northern part of the islands of Papua and Halmahera. This zone is generally also characterized by the presence of a deep enough trough. In Indonesia, a series of volcanoes are part of the Asia-Pacific which is often referred to as a ring of fire [1].

This geological reality means that Indonesia will always be threatened by earthquakes that can cause tsunamis. The most devastating earthquake and tsunami that occurred on December 26, 2004, with a magnitude of 8.9 on the Richter scale devastated all aspects of the life of the Acehnese people. As a result, 110,299 people died, 12,132 people disappeared and 703,518 people lost their homes [2]. Likewise, the economic loss of around US \$45,000 million, [3]. Referring to the report from the Indonesian Disaster Management Agency (BNBP) that 10 types of disasters can endanger human lives, namely; earthquakes, tsunamis, volcanic eruptions, floods, landslides, droughts, land and forest fires, extreme weather, extreme waves and abrasions, and flash floods [4].

BNBP in the design of natural disaster risk reduction in Indonesia makes religion and attitude of life important elements in disaster management so that religious leaders are always present [5]. BNPB realizes that religion as a source of social capital can build community resilience to disasters and reduce disaster risk. The use of religion and local wisdom is also used by the Balinese who are predominantly Hindu. According to Dasgupta [6] that the Balinese people believe that Bhuana Agung and Bhuana Alit have an integralists cosmic relationship. Therefore, all the life activities and rituals of Hindus always glorify and maintain the cosmic which is based on human consciousness centered on nature (kosmos).

Aceh as an area that was once the epicenter of the earthquake actually has social capital in the form of 
local norms traceable to Simeulu which is known as smong. Smong are local values known through stories and songs passed down from generation to generation by the Simeulu community. The smong was proven to have saved hundreds of lives when the tsunami occurred in 1907 and 2004, which is directly adjacent to the Indian Ocean [7].

Like among, religious norms in Banda Aceh have proven to provide a strong foundation in shaping mental resilience to disaster. Suwignyo [8] emphasizes that people who lost their property and family after surviving the tsunami have religious beliefs and help to get through difficult times. The success of social capital as a weapon in dealing with something that endangers humans has also proven to be successfully used by the people of Ujoeng Pacu, Lhokseumawe, Aceh against the drug mafia. The socio-religious capital becomes the glue that unites the community in eradicating these illegal items [9], [10].

This can happen because religion, which has a set of values for humans in facing life, both for individual and social matters, is often ignored and ignored. Any religion, including Islam, is impossible to teach something immoral, especially if it has a negative impact not only on humans themselves but extends to all living things, even nature [11].

Therefore, this study will discuss religion as social capital in realizing disaster resilience in Banda Aceh City. This study is important to do to explain how religion along with its norms and values can become a social force in dealing with disasters, especially earthquakes and tsunamis.

\subsection{Formulation of the Problems}

Social capital consists of norms, networks, and trusting relationships that give birth to collectivity [12]. Norms or values that can come from religion and sociocultural order. In the context of Acehnese society, the dominant norms and values come from religion, namely Islam. Meanwhile, disaster resilience is the capacity of a community or society that has the potential to be exposed to disasters to adapt to ways of surviving the social system of society [13], [14].

The disaster in question is the earthquake and tsunami that hit Aceh. Therefore, to direct this study to be more focused, the following will be discussed in the research, namely; 1) How can religion become the social capital of the Acehnese people in realizing disaster resilience? 2) What religious norms or values can be used as social capital for the community in realizing disaster resilience?

\section{LITERATURE REVIEW}

\subsection{Previous Review}

Studies on the religion of social capital associated with disaster resilience have not been widely carried out by researchers in Indonesia. Some of them are written using a theoretical perspective without using field data, some are studying them with field data but do not relate it to religion as social capital. Most of the studies on disaster are studied from local wisdom, although some of these studies will be used as part of the literature review to find the start of the art of the study that is being carried out.

Among the studies on social capital and disasters, namely; Marfai [15] examines the role of local wisdom and social capital in disaster risk reduction and coastal development. This study concludes that local wisdom is a powerful social capital in reducing disaster risk in Indonesia, especially in Demak, Central Java, and India. Zal [16] writes about the resilience of flood victims communities on the east coast of the Malaysian peninsula. He concluded that social capital can contribute to increased knowledge/skills, relationships between communities, elements of income and assets, the availability of basic principles and knowledge, the dependence on and the practice of the respondent's religion.

Marfai's study is more global regarding disasters in general such as those that occurred in Indonesia and India, while Amri Zal is more specifically about the flood disaster in Malaysia but has a common thread, namely the importance of social capital in dealing with disasters. Meanwhile, Paramitha, Fathimasyam studied disasters from a theological or religious perspective. Dasgupta [15] discusses disasters from a religious perspective and Balinese local wisdom. In Balinese culture, bhuana agung and bhuana alit have an integralistic relationship. Whatever happens in bhuana agung, has a direct relationship with bhuana alit - and vice versa. All kinds of ritual activities performed by Hindus in Bali to glorify and maintain cosmic balance are based on the emergence of a nature-centered human consciousness (kosmos). All human religious expressions are oriented towards the cosmos sanctifying mountains, lakes, forests, and seas. Phenomenologically, the intentionality of human consciousness that is centered on nature has shaped the beliefs and culture of the Balinese people.

In line with that, Fatimahsyam's fourth study, [16] offers anthropocentric theology, which is a theology that places humans at the center of their orientation, as the core of humanizing and prospering. This theological paradigm is believed to be dialogically capable of realizing human godliness by itself, with humanity without changing the form of monotheism in the concept of disaster management. This study assesses Asyariyah theology as fatalistic and resigns to destiny. It is not fatalistic Asy'ariyah, but Jabariyah theology means accepting destiny without any effort. Imam Asyariy believes that everything that happens is destiny, but in that case, there is a human role called al-kasb, or human effort and effort. This study also focuses more on literature studies, as a result of which it has less relevance to the social reality of the Acehnese people who mostly adhere to Asyariyah theology.

Sari, Husin and Syamsidik [17] study that local 
wisdom has a strong impetus to reduce disaster risk. Smong, as a local wisdom in Simeulu, has become a social asset that prevents the community from being victims of the tsunami. Whereas geographically Simeulu is in the middle of the Indian Ocean which was the epicenter of the 2004 earthquake and tsunami. Social memories are in the form of folk tales, song lyrics transmitted from older generations to younger generations, even through the cultural media of nandong and nafi-nafi.

Therefore, the vague study of religion as social capital in realizing disaster resilience in Aceh will be explored more clearly and deeply. This study is important to do because, firstly, the social system and cultural structure of Aceh are indeed thick with religious norms and values; second because Aceh was hit by the 2004 earthquake and tsunami which was the biggest in world history.

\subsection{Theoretical Perspective}

The theory used in this research is the social capital theory. Social capital is based on norms, networks, and trusting relationships that grow from both sides so that people can move together collectively [18]. Social capital consists of two that attach social relationships (bonding social capital) and social capital that bridge social relationships (bridging social capital). The social capital that sticks together is social capital that can integrate social relationships so that one person gives attention to each other and helps solve problems together. Then the social capital that bridges the social relationship is social capital that allows one social group to access the resources owned by another social group.

Likewise, Putman [19] also acknowledges that social capital consists of two types, namely cognitive and structural social capital. Cognitive social capital consists of values, values, and behaviors that give birth to a sense of trust among community members in their social relationships. Then structural social capital in a variety of activities, organizational structures, and democratic principles that support collective action and in decision making [20].

According to Paldam, social capital is the glue that holds people together. Paldam divides the theoretical approach to social capital into trust, cooperation, and networking. The same trust applies between trust and network. The network will function optimally when trust is built between social groups [21]. Meanwhile, according to Coleman, social capital is not a single entity, but a variety of diverse entities with two common elements consisting of various aspects of the social structure and facilitate the actions of certain actors in other structures. Social capital is not fungible but may be specific to certain activities. Unlike social capital, it is inherent in the structure of the relationship between actors and actors [22].

Meanwhile, Caldwell [23] explains that social capital refers to the capacity of individuals to acquire material goods or symbols of value based on the virtue of social relationships and membership in social groups or a person's plurality capacity to enjoy the benefits of collective action based on the virtues of social participation, trust in institutions. and a commitment to establishing a way of doing things.

Therefore, social capital does not only see results but is more concerned with processes. It undergoes continuous formation and always accumulates itself and develops better if it is always used. This is because the general factors that influence the formation of social capital are; habits, roles, and positions of actors, education, socio-economic class, and personal values. Social capital rests on the notion of beliefs, norms, and informal networks and believes that social relations are a valuable resource [24].

Thus, the essence of social capital is the norm or value, network, and trust relationships. In the context of social capital research, elaboration is the norms and values contained in the social structure and order of society. These norms and values are fanatically adhered to and the majority in Acehnese society. This social capital theory will serve as an analytical blade in studying the relationship between religion and disaster resilience in Acehnese society.

\section{RESEARCH METHODOLOGY}

This study used a qualitative study (qualitative approch). Bogdan and Taylor as mentioned by Moleong [25] and Denzin \& Yvonna [25] say that qualitative research is a research procedure that produces descriptive data in the form of written or spoken words from people and observable behavior. While the approach used is ethnography which is commonly used in social research [26].

Data collection techniques used are; first, interviewing techniques were used to strengthen questionnaire data and documents. Interviews are questions and answers between researchers and respondents to obtain the required data [27]. This technique will be used to obtain data from key informants, namely religious leaders, community leaders and affected communities. Second, document studies, in social research and ethnographic studies, the use of documents is important enough to support other techniques. The documents in question are; daily notes, daily journals, autobiographies, statistical data, activity reports and all documents related to the theme being researched. Then the data analysis technique is the process of organizing and sorting data into patterns, categories and basic description units [28]. More than that, all data obtained from observations, interviews and document studies were analyzed by means of triangulation, namely matching each other from the various data collection techniques above. 


\section{RESULTS AND DISCUSSION}

\subsection{Religion as a Social Capital}

The main provision possessed by the people of Aceh is a strong religious belief so that they depend only on Allah SWT. The people of Aceh in any condition, will need religion and ask, depending only on Allah who is all-hearing, seeing, knowing, and at the same time most merciful. The Acehnese people believe that God is the Creator who hears complaints, the cry of the heart that cannot be revealed [29].

According to DM, a lecturer at the State Islamic University Ar-Raniry, religion is the main social capital for the people of Aceh in facing disasters including earthquakes and tsunamis. History proves that throughout the decade's society was hit by conflict when they fought against the colonialists and their main capital in the struggle was religion. Then during the earthquake and tsunami, they were also tested for their psychological resistance. The souls of Acehnese people are strong in religion and aqidah in the face of conflicts against the colonialists, humanitarian conflicts for more than 30 years, let alone rise after the tsunami [30].

In line with that, NA was one of the survivors of the earthquake and tsunami at the Baiturrahman Grand Mosque when he ran from the shop where he worked, which is about 200 meters away, that there were around 400 survivors at the mosque. According to him, he ran as hard as he could to the mosque because he believed that the mosque was the house of Allah and a sacred religious building that could be the reason for surviving the tsunami waves. With the power of Allah the tsunami water did not enter the mosque but only at the side and yard. He was in the mosque for about an hour when the tsunami waves came at an incalculable speed. The tsunami waves hit accompanied by aftershocks [31].

In this context, religion as social capital can become the glue that unites the people in the Paldam language, or according to Putman as cognitive social capital whose values and behaviors create trust. The values and behavior that then give birth to a sense of trust and power come from the religion believed by the people of Aceh.

\subsection{Norms, Religious Values and Disaster Resilience}

\subsubsection{Tauhid}

Tauhid is a norm and value that is very prominent in Acehnese society. This can be seen when someone is hit by a disaster such as the 2004 earthquake and tsunami in Banda Aceh. One of Ms. HA, who survived the Tsunami Wave when she ran and got into the boat in the Lampulo area. He said that that morning at around 8:00 a.m. the earthquake shook Aceh which was very powerful, we could not be able to stand up or even walk. About 25 minutes later several people shouted while running "the sea is rising", we ran up to the 2nd floor. A few minutes later the water reached the waist of an adult on the second floor. At that time we were only doing zikir and praying in the house. Then a few moments later a boat was washed ashore in a residential area. We also got on the boat for about 5 hours we were on the boat. While we were on the boat we stopped reciting the Koran, praying, and remembrance Allah. It turned out that the empty boat was inside, a jerry can containing drinking water, a knife, and several pieces of cloth. We say Subhanallah, Alhamdulillah, and Allahu Akbar. Allah with his power deliberately sent the boat to save us. The number of people who survived on the boat was 59 people (Panitia Peringatan Gempa Bumi dan Tsunami Gampong Lampulo Kecamatan Kuta Alam Kota Banda Aceh, 2011: 3-7).

According to DM, a lecturer at the State Islamic University ar-Raniry is the strongest fortress of the Acehnese people so that they can survive and even rise from the impact of the earthquake and tsunami. Because of that we have never seen and heard that there are Acehnese suffering from mental disorders or even suicide because their families are victims of the disaster or their assets are used up. Perhaps this is what distinguishes the character of the Acehnese people from other communities in Indonesia or in other countries [32].

In line with that, LM's testimony was also in the boat, he said that from the direction of the sea there had been large waves many times, I stood on the deck of the boat facing the sea while saying the call to prayer several times, the wave broke. The other passengers also made dhikr, tahlil, tahmid, and prayed to Allah SWT that we were saved from the disaster (Panitia Peringatan Gempa Bumi dan Tsunami Gampong Lampulo Kecamatan Kuta Alam Kota Banda Aceh, 2011: 14).

The explanation above shows that the people of Aceh have strong tauhid and aqidah. That is the relationship between servant and God as the Almighty Creator and Almighty over everything. It is proven that when in a state of disaster and disaster, remembering to Allah is still maintained, in the form of zikir, praying, praising Allah, reading the Qur'an.

\subsubsection{Sabar}

Patience (sabar) means steadfastness, persistence, resilience, the endurance of suffering, without being anxious, without complaining. Therefore, patience will be able to keep away from feelings of anxiety, restlessness, and frustration, on the contrary, patience will bring inner peace. By being patient, humans will be educated psychologically to strengthen their personalities and increase their ability to endure difficulties, face life's problems, and disasters and calamities. Patience can also generate the ability to continue a more optimistic life [33].

Muslims according to the holy book they believe teach that calamities and trials all come from Allah whose purpose is to test humans. All these calamities and trials are Allah's way of testing humans whether 
they are patient or not facing them as stated in QS. AlBaqarah: (155-157).

The patience of the Acehnese in dealing with calamities and disasters was shown by Ms. MS (55 years at the time of the tsunami), her house was destroyed, her furniture was exhausted, some of her family died. His son, VN, was sick because of drinking a lot of tsunami water, his breathing was disturbed and his lungs were dirty. VN was brought to Medan and Mrs. SM and was treated for 44 days there. After returning from Medan it was impossible to return to his house in Banda Aceh because his residence was completely exhausted, he stayed in North Aceh with his younger brother for 1 month. After that, they lived in limited rental rooms because there were not many houses for renting the price soaring at that time because many NGOs and NGOs from Jakarta or overseas had come to Banda Aceh to carry out post-tsunami reconstruction and rehabilitation [34].

Ms. MS's patience should be used as an example because she lost her house, furniture, lost relatives, stayed with relatives, rented a place to live until she finally returned to her original home in Lamdingin, Banda Aceh.

\subsubsection{Tawakkal}

Tawakkal is surrendering to God which means the complete acceptance of the reality of oneself and the results of its efforts as it is, or in other words willing or able to adapt to oneself. If a person is not able to accept the situation as it is, then he will feel depressed, anxious, anxious, and even more than that. Someone who has a tawakkal attitude will feel depressed, anxious, anxious, and afraid of disappearing from a person (MUI Compilation Team, 2005: 23).

This tawakkal attitude can be seen from the confession of Ms. MS, that the tsunami was thrown from her residence in Lamdingin Village, Kuta Alam District to the Kerueng Cut area, Tibang, about $5 \mathrm{Km}$. Initially, she held hands with her son Novi for several hours, the second wave came with her son strongly escaping from her grasp. He then put his trust in him while praying "O Allah, save my son, extend his age and meet me with him before he dies". When he saw a large wave and a snake that was ready to pounce on him he did not stop reciting zikir, subhanallah, lailahaillalah, alfatiha, and the prayers he memorized. He was able to survive from 9 to 4 in the afternoon on a pile of wood that was carried away by the tsunami. At $4 \mathrm{pm}$ after the water calmed down, he was rescued by a fishing boat returning from the sea. On the boat, several people were lying dead and seriously and lightly injured, about a dozen people [35].

Tawakkal is closely related to faith, faith will not exist without tawakkal. Tawakkal also means entrusting oneself to Allah and as proof of one's faith. Tawakkal does not mean resigning, being passive without effort and running away from reality. On the contrary, tawakkal is an active attitude that grows only from a person who understands life properly and accepts the realities of life as well.

\subsubsection{Ikhlas}

Sincerity (ikhlas) in this sense is an attitude of someone who can accept calamities that befell him or his family without complaining, without blaming others let alone blaming God. Sincerity in doing is doing something selflessly, without expecting anything in return, but accepting anything from God without problems [36].

For the sincerity of the Acehnese people in accepting the disaster, DM, a lecturer at the State Islamic University ar-Raniry explained, I saw and had a direct dialogue on the day of the tsunami at the Mosque Jami ' Kopelma Darussalam in Banda Aceh, there was a man who lost his wife and 7 children and their belongings. When I asked him how he was with the loss of loved ones and belongings, he firmly said that let alone wife, children, and property, I belong to God, if I too will be taken by God, I am sincere and willing [37].

Likewise, Ms. MS's sincerity in accepting the tsunami that she experienced, being played with by the waves, lost her house, and other assets. Instead, he can say: "Thank God for not opening my genitals in front of the sea people. He also said Alhamdulillah because he did not feel deep or heavy wounds like other people who were swept away by the tsunami " [38].

The statement that "let alone the wife, children, and property, I also belong to Allah and I am sincere and willing if Allah takes me" from a person who has lost his wife and the goals of his children. Also "Alhamdulillah, for not feeling deep or heavy wounds like other people who were carried away by the tsunami" are two expressions and a sincere attitude of a servant to Allah. A person who has reached the stage of sincerely accepting trials, disasters as a destiny from Allah will psychologically, have an open soul, and his heart willingly accepts the loss. Conversely, someone who is unable to accept fate is not sincere with the reality that befell him, then they will lose, he will be stressed, depressed and even will experience prolonged mental disorders.

\section{CONCLUSION}

The discussion shows that the people of Aceh, especially in the city of Banda Aceh, religion can become social capital in facing and surviving disasters, especially earthquakes and tsunamis. Then norms and religions such as tauhid, sabar, tawakkal and ikhlas can become valuesand attitudes that give birth to a strong sense and power in Putman's language in the face of this disaster.

\section{ACKNOWLEDGMENTS}

The author would like to thank you so that this research can be carried out, namely; Malikussaleh University and all staff who provide research funding, 
parties willing to be interviewed, the ranks of the Faculty of Social and Political Sciences and the entire committee organizing the international seminar ICoSPOLHUM.

\section{REFERENCES}

[1] BNPB, 2016

[2] BRR NAD-NIAS, 2005

[3] BNPB, 2016: 56

[4] BNPB, 2016: 122

[5] BNPB, 2016: 122

[6] Dasgupta, Paramita, et al. "Geographical variations in prostate cancer outcomes: a systematic review of international evidence." Frontiers in oncology 9 (2019): 238.

[7] Dasgupta, Paramita, et al. "Geographical variations in prostate cancer outcomes: a systematic review of international evidence." Frontiers in oncology 9 (2019): 238.

[8]. Sari, Rasli Hasan, and Syamsidik Taqwaddin Husin. "Kearifan Lokal Smong Masyarakat Simeulue Dalam Kesiapsiagaan Bencana 12 Tahun Pasca Tsunami." Jurnal Ilmu Kebencanaan: Program Pascasarjana Unsyiah 3.1 (2016).

[9]. Sari, Rasli Hasan, and Syamsidik Taqwaddin Husin. "Kearifan Lokal Smong Masyarakat Simeulue Dalam Kesiapsiagaan Bencana 12 Tahun Pasca Tsunami." Jurnal Ilmu Kebencanaan: Program Pascasarjana Unsyiah 3.1 (2016).

[10] Nirzalin, Nirzalin, and Yogi Febriandi. "Teungku Dayah Agency and Religious Social Capital on Drug Eradication in Aceh, Indonesia." Jurnal Ilmu Sosial dan Ilmu Politik 23.3 (2020): 210222. DOI: https://doi.org/10.22146/isp.51061

[11] Nirzalin, Nirzalin, Zulfikar Zulfikar, and Fakrurrazi Fakrurrazi. "Agama dan Modal Sosial Gerakan Pemberantasan Narkoba di Aceh." LPPM Unimal (2018).

[12] Narayan, D., \& Cassidy, M. F. (2001). A dimensional approach to measuring social capital: development and validation of a social capital inventory. Current sociology, 49(2), 59102. doi.org/10.1177/0011392101049002006.

[13]. Sukmana, Enriko Tedja. "Revitalisasi Keharmonisan Dunia (Menilik Relevansi Antara Moral, Agama, dan Bencana)." ESENSIA: Jurnal Ilmu-Ilmu Ushuluddin 14.1 (2013): 1-18. DOI: https://doi.org/10.14421/esensia.v14i1.747

[14] UN/ISDR. (2004). Living With risk. A Global Review of Disaster Reduction Initiatives, InterAgency Secretariat of the International Strategy for Disaster Reduction (UN/ISDR).

[15] Dasgupta, Paramita, et al. "Geographical variations in prostate cancer outcomes: a systematic review of international evidence." Frontiers in oncology 9 (2019): 238.
[16] UN/ISDR, (2004). Global Assessment Report on Disaster Risk Reduction: Revealing Risk, Redefining Development, Information, Press, UK: Oxfrod.

[17]. Sari, Rasli Hasan, and Syamsidik Taqwaddin Husin. "Kearifan Lokal Smong Masyarakat Simeulue Dalam Kesiapsiagaan Bencana 12 Tahun Pasca Tsunami." Jurnal Ilmu Kebencanaan: Program Pascasarjana Unsyiah 3.1 (2016).

[18] Narayan, D., \& Cassidy, M. F. (2001). A dimensional approach to measuring social capital: development and validation of a social capital inventory. Current sociology, 49(2), 59102. doi.org/10.1177/0011392101049002006.

[19] Putman, Charles T., et al. "Chronic low-frequency stimulation upregulates uncoupling protein-3 in transforming rat fast-twitch skeletal muscle." American Journal of PhysiologyRegulatory, Integrative and Comparative Physiology 287.6 (2004): R1419-R1426.

[20] Fukuyama, Francis. Trust: The social virtues and the creation of prosperity. Vol. 99. New York: Free press, 1995.

[21] Laba, K. Dampak Pemekaran Kabupaten terhadap Akumulasi Stok Modal Sosial dalam Pertumbuhan Ekonomi di Wilayah Pesisir: Kasus Wilayah Pesisir Teluk Lewolebata Kab. NTT, Tesis, Bogor: Sekolah Pascasarjana IPB. 2006.

[22] Eko, S. Modal Sosial, Desentralisasi dan Demokrasi Lokal. dalam Jurnal Analisis CSIS, 33(3). 2004.

[23] Caldwell, Melissa L. "Domesticating the French fry: McDonald's and consumerism in Moscow." Journal of Consumer Culture 4.1 (2004): 5-26.

[24] Fathy, R. (2019). Modal Sosial: Konsep, Inklusivitas dan Pemberdayaan Masyarakat. Jurnal Pemikiran Sosiologi, 6(1), 117. DOI: https://doi.org/10.22146/jps.v6i1.4746 $\underline{3}$

[25] Moleong, L. J. Metodologi penelitian kualitatif. Bandung: Rosda Karya. 2019.

[26]. Duranti, A. Husserl, intersubjectivity and anthropology. Anthropological theory, 10(1-2), 16-35. 2010.

[27]. Supranto, J. Metode Riset. Rineka Cipta, Jakarta. 1997.

[28] Moleong, L. J. Metodologi penelitian kualitatif. Bandung: Rosda Karya. 2019.

[29] Tim Penyusun MUI, Pedoman Bimbingan Keagamaan Bagi Korban Bencana Alam, Jakarta: Majelis Ulama Indonesia. 2005.

[30]. Interview with, DM, Lecturer at State Islamic University of Ar-Raniry Banda Aceh, 24 Oktober 2020.

[31] Interview with, NA is a tsunami survivor at a Baiturrahman Mosque in Banda Aceh, 16 Oktober 2020. 
[32] Zal, WA Amir. "Ketahanan Komuniti Mangsa Bencana Banjir Di Pantai Timur Semenanjung Malaysia Dalam Konteks Modal Komuniti [Community Resilience Among Flood Victims In The East Coast Of Peninsular Malaysia In The Context Of Community Capitals]." Journal of Nusantara Studies (JONUS) 3.2 (2018): 41-53. DOI: https://doi.org/10.24200/jonus.vol3iss2pp4 $\underline{1-53}$

[33] Tim Penyusun MUI, Pedoman Bimbingan Keagamaan Bagi Korban Bencana Alam, Jakarta: Majelis Ulama Indonesia. 2005.

[34] Interview with, MS, housewives, who survived the tsunami in Lamdingin Banda Aceh, 17 Oktober 2020.

[35] Interview with, MS, housewives, who survived the tsunami in Lamdingin Banda Aceh, 17 Oktober 2020.

[36] Tim Penyusun MUI, Pedoman Bimbingan Keagamaan Bagi Korban Bencana Alam, Jakarta: Majelis Ulama Indonesia. 2005.

[37]. Interview with, DM, Lecturer at State Islamic University of Ar-Raniry Banda Aceh, 24 Oktober 2020.

[38] Interview with, MS, housewives, who survived the tsunami in Lamdingin Banda Aceh, 17 Oktober 2020 . 